\title{
Heuristic Talk as a Means of Forming a Teenager as a Subject of Educational Activity
}

\section{Евристична бесіда як засіб формування підлітка як суб'єкта пізнавальної діяльності}

\author{
Nataliia Ternovyk \\ Ph. D. in Psychology, Assistant Professor, International Eco- \\ nomic and Humanities University named after Stepan Demianchuk, \\ Rivne (Ukraine) \\ ORCID ID: https://orcid.org/0000-0002-1425-2423 \\ Researcher ID: http://www.researcherid.com/rid/AAH-8779-2020 \\ E-mail: nato4ka66@ukr.net

\section{Наталія Терновик} \\ Кандидат психологічних наук, доцент, Міжнародний еконо- \\ міко-гуманітарний університет імені академіка Степана Дем'янчу- \\ ка, м. Рівне (Україна)
}

\section{Oleksandr Hudyma}

Ph.D. in Psychology, Assistant Professor, Department of General and Applied Psychology, Kamianets-Podilskyi National Ivan Ohiienko University, Kamianets-Podilskyi (Ukraine)

ORCID ID: https://orcid.org/0000-0001-8244-7284

Researcher ID: http://www.researcherid.com/rid/F-8900-2019

E-mail: hyduma1979@ukr.net

\section{Олександр Гудима}

Кандидат психологічних наук, доцент, кафедра загальної та практичної психології, Кам'янець-Подільський національний університет імені Івана Огієнка, м. Кам'янець-Подільський (Україна)

Address for correspondence, e-mail: kpnu_lab_ps@ukr.net Copyright: (C) Ternovyk Nataliia, Hudyma Oleksandr

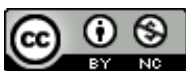
The article is licensed under CC BY-NC 4.0 International (https://creativecommons.org/licenses/by-nc/4.0/)

C Ternovyk Nataliia, Hudyma Oleksandr

DOI (article): https://doi.org/10.32626/2227-6246.2021-51.190-214 http://journals.uran.ua/index.php/2227-6246 
DOI: https://doi.org/10.32626/2227-6246.2021-51 2021. ВИПУСК 51

The author's contribution: Ternovyk N. - 50\%, Hudyma O. - 50\%. Авторський внесок: Терновик Н. - 50\%, Гудима О. $-50 \%$.

\section{ABSTRACT}

The purpose of our research is to justify methodological backgrounds for the purpose of investigating subjectivity of the person and to test the level of person's formation of adolescents empirically in the heuristic talk.

The following theoretical methods of the research were used to solve the tasks formulated in the article: a categorical method, structural and functional methods, the methods of the analysis, systematization, modeling, generalization. The questionnaire method was used as the experimental one. In order to conduct the empirical part of the research, the author's questionnaires were developed for both parents and teachers.

The results of the research. Current experimental data suggest that group activity has a positive effect on individual pupils' activity. In our experiments we found that the productivity of random memorization of words (the reproduction) of pupils in the presence of others increased by $3 \%$, and in terms of joint activities - by $25 \%$. Thus, in the conditions of interaction of pupils the exchange of information communication performs the function of forming a common memory fund. The results of experiments conducted under the direction to solve problems that require a creative approach are indicative for the confirmation of greater efficiency of group activity in comparison with individual. In this research a large number of pupils were offered the same task. During 30 minutes provided for solving the problems, none of the pupils were able to cope with it, working individually. Then the task was offered to groups of the same pupils, united by 2-3 and 4 people. $70 \%$ of the groups found the right solution without going beyond the same 30 minutes.

Practical experience in the use of group forms of the activity at the lessons allows us to explore the relationships between the effectiveness of joint activities of pupils in the process of group activity on the effectiveness of individual solution by partners in the process of communication of mental problems. At the lessons groups of pupils (3-4 pupils in each group) were asked to solve some problem. As an indicator to assess the effectiveness of joint activities of adolescents in the process of group activity, we used the measure of a teacher's assistance to pupils. As a result, teenagers were divided into subgroups (depending on how much help they needed from the teacher in solving the problem). The first (best)

(C) Ternovyk Nataliia, Hudyma Oleksandr DOI (article): https://doi.org/10.32626/2227-6246.2021-51.190-214 
subgroup included groups of pupils who showed the highest level of efficiency in solving problems in the process of joint activity, the second (average) - groups with average efficiency, the third (worst) - triads with the least efficiency in the performance of tasks.

Conclusions. These factors must be taken into account by teachers in the classroom to increase the level of knowledge of pupils in this or that subject and improve the methods of working with pupils within the implementation of an individual approach to each individual adolescent. It should be emphasized that the effectiveness of group forms of work at the lessons is largely determined by the level of the activity of pupils' thinking, which in turn will depend on several conditions: whether pupils will receive knowledge ready, if the teacher fully explains the new topic (but does not retell the task, accompanying the translation with the only correct explanation and evaluation of the material, which sometimes occurs in the pedagogical practice of teachers); whether the teacher seeks to include pupils into the process of studying the material through leading questions; whether the study of new material is carried out in the process of independent search activity of pupils who, when faced with a problem situation, themselves seek a way out of it, thus solving a cognitive problem.

Key words: heuristic talk, a subject of educational activity, pupils' thinking, the process of joint activity, the interaction of pupils, the communication, mental problems.

\section{Introduction}

The humanization of the educational process of the contemporary school is primarily focused on preserving the exclusivity and uniqueness of each person (Brédart, 1991). After all, we have to tell about all children, the future of our society and state. Therefore, it is necessary to pay attention to the development of the person's subjectivity and those important qualities that reflect the individuality. The widest possibility of the realization of individual qualities of a child appears in the process of educational activity (Beauvillain, 1994). And last but not at least it is the creation of effective psychological conditions for the development of pupils as subjects of their cognitive activity (Crookes, 1989).

C Ternovyk Nataliia, Hudyma Oleksandr

DOI (article): https://doi.org/10.32626/2227-6246.2021-51.190-214 
One of the ingrained trends at school teaching is that a pupil is perceived more as the object of the pedagogical influence than as a subject of learning. The teacher and the schoolboy / girl are in a situation of threat of misunderstandings and conflicts. This is especially true for adolescents with a higher level of self-awareness, the ability to self-realization and the desire for self-affirmation (Britell, 1980; Chen, 1993).

Thus, the formation of the adolescent, the development of his / her independence, the growth of the person as a subject of cognitive activity, the fullest realization of the creative potential of a student remain the most important tasks of the educational process of the contemporary school.

The purpose of our research is to justify methodological backgrounds for the purpose of investigating subjectivity of the person and to test the level of person's formation of adolescents empirically in the heuristic talk.

\section{Methods of the research}

The following theoretical methods of the research were used to solve the tasks formulated in the article: a categorical method, structural and functional methods, the methods of the analysis, systematization, modeling, generalization.

\section{Results and their discussion}

It should be emphasized that along with the psychology of the person, the psychology of the individuality as a traditional direction of the world psychology, the psychology of subjectivity is actively trying to assert itself. It is known that one of the most common norms is the image of the subject. The subject in this context is considered as a source of consciousness of human activity. The image of the subject performs a regulatory function in the society and historically develops in the process of social practice. Its main features are learned by a person during communication and especially actively during training.

(C) Ternovyk Nataliia, Hudyma Oleksandr DOI (article): https://doi.org/10.32626/2227-6246.2021-51.190-214 
DOI: https://doi.org/10.32626/2227-6246.2021-51 2021. виПуСК 51

Before manifesting oneself in the process of social interaction, a person tries to anticipate his / her actions, to rebuild his / her self-image in a certain situation (Mykhalchuk \& Bihunova, 2019). Such awareness of himself / herself as an actor, as a source of one's own activity, is based on generally accepted ideas about the subject. They are the basis of the individual's reflections, his / her vision of his / her «Self» from the side of others (Adler, Lindzey \& Hall, 1997).

Thus, in order to influence the development of adolescents purposefully in the process of cognitive activity, scientists have to present the image of subjectivity clearly, which is reflected in certain aspects of the activity, such as: conditionality of mental image by past experience, needs, attitudes, emotions, goals and motives controllability and selectivity of the activity. The formation of the subject involves the emergence of processes of the development and prioritization of goals, problems and choices for solving and shaping tasks and solutions. In such a way subjectivity is essentially socio-cultural in nature, as the ultimate cause of an individual's actions is always characterized in time, space, meaning, and among the direct and indirect participants in the activity.

The learning process would promote the development of the adolescent as a subject of the activity, strengthen pupils' interest in learning, discovering new, ensuring the reliability of acquired knowledge and at the same time promoting the formation of each child's traits of having been cognitive active, characterizing by real and creative thinking, self-critical personality.

The experience shows that psychological and pedagogical material has been collected, which allows to see us the ways of specific psychological and pedagogical activity that activates the subjective forces of the adolescent's person (Bennett, 1998; Bondarenko \& Levenetz, 2000). But to date, there have been no special psychological studies that would consider the problem of forming a teenager as a subject as one of the important (C) Ternovyk Nataliia, Hudyma Oleksandr

DOI (article): https://doi.org/10.32626/2227-6246.2021-51.190-214 
components of personality's development in cognitive activity in the process of schooling.

In the context of this problem we note that subjectivity affects the development of the personality primarily because it serves as the important form of individual connection with the society, the realization of personal and social interests, the identification of the individuality, self-awareness, self-organization and self-realization during cognitive activity. It also confirms the contradiction between the growing demands of the contemporary school and the individual qualities of the adolescent's personality and the level of the development of his / her subjective essence (subjectivity). Theoretical development and practical significance have identified the problem of our research - what psychological conditions are the most effective in terms of the development of the adolescent as a subject of cognitive activity.

The idea of the personality, or «human of a man» has always worried scientists, philosophers, psychologists, educators, because not a man belongs to the body, but the body to a man (Abrams \& Hogg, 1999). Individuals are born, they become a personality, they defend individuality (Dubovyk, Mytnyk, Mykhalchuk, Ivashkevych \& Khupavtseva, (2020). The famous scientists consider the idea of human subjectivity as a kind of self-determination of his / her existence in the world (Das, 2009; Onufriieva, Chaikovska, Kobets, Pavelkiv \& Melnychuk, 2020). The phenomenon of subjectivity is that man sees himself / herself as the cause of his / her personal existence in the world, which is manifested in acts of free going beyond the established process (detection of active human maladaptation), reflection of himself / herself in other people (being in the other person and for the other one) and in himself / herself (being in himself / herself and for himself / herself). Psychology, being separated from Philosophy over time, does not abandon the personal subject, but continues to develop it due to its own specifics. We have to note that historically, 
DOI: https://doi.org/10.32626/2227-6246.2021-51 2021. випуск 51

Ukrainian psychology has relied and still relies mainly on materialist views. Since 1920 s, the problem of the methodological role of the category of "subject» for determining the subject of psychology has been actively developed in the world psychology. The development of a subjective approach is associated with the names of many scientists (Drobot, 2013).

Thus, scientists point out that the activity can not be performed by itself, the activity can only be the activity of one's entity (he / she is the author, the creator, the performer) or entities that perform joint activities. In addition, the activity is always objective, real, creative and independent. Independence does not contradict joint activity, it is realized in it. Researchers pointed out to the relationships between the development and being of the subject. The subject is a part of being, knowing which one creates it. In turn, changes in being lead to a change of the subject as a component of being. Thus, being creates the subject, and he / she, in turn, creates his / her own being (Caljuve, Marx \& Petry, 1993).

Also scientists made a significant contribution onto the development of a subjective approach. In such a way the scientist noted that active relations with the reality are not individual acts of mental activity of the subject, but the subject himself / herself. In addition, they believed that the man is a subject at all levels of his activity, as any activity means the subject's attitude to the surrounding reality (Vovk, Emishyants, Zelenko, Drobot \& Onufriieva, 2020). We believe that such a view is acceptable only in a case of conscious activity. It is clear that the unconscious individual is incapable of reflection as a structural component of consciousness. Therefore, he cannot separate himself from the world, separate himself from his own life; does not know that his activity depends on him. Therefore, in addition to unconscious activity the individual must initiate his conscious activity. Then we can really say that at all levels of conscious activity a person is a subject.

C Ternovyk Nataliia, Hudyma Oleksandr

DOI (article): https://doi.org/10.32626/2227-6246.2021-51.190-214 
Among the luminaries of the subjective approach is A. Bine (1987), who, highlighting the triad «the individual - the personality - the individuality" correlated it with the understanding of a man as a subject of knowledge, communication and the activity. A. Bine (1987) believed that the integration of all the characteristics of man as an individual, personality, the subject of the activity, their merger is individuality. Individuality is one of the latest products of human development, the highest level of the development of subjective activity, due to the fact that a high coefficient of exteriorization, of the activity allows a person to build himself / herself from the very beginning.

A. Bine (1987) noted that the formation of the person occurs much later than the formation and the development of the individual. In addition, in his opinion, the subject is always a person, and the person is a subject. But he / she does not identify these concepts, as there is a difference in their characteristics (activities and attitudes), and in the affiliation of these characteristics to more general structures. Therefore, scientists note that the subject is not only the individual, but the individual is not only the subject. So, if we compare these two statements, we get that a person does not born as a subject. Continuing the analysis of human ontogenesis by A. Bine (1987), we find that the social formation of a man is not limited to the formation of the person - the subject of social behavior and communication. This is at the same time the creation of a man as a subject of knowledge and the activity. And we must admit that the formation of these qualities precedes the formation of personal qualities.

So, it is logical to assume that in terms of genesis, according to scientists, we have an individual, a subject, a Person. We do not believe that the subject is always a Person. Personality, in our opinion, is a qualitatively new level of the development of the subject. The opinion of researchers is close to us, that at a certain stage of life every child becomes a person,

(C) Ternovyk Nataliia, Hudyma Oleksandr DOI (article): https://doi.org/10.32626/2227-6246.2021-51.190-214 
and each person is a subject (although the latter, as we have seen the subject is not reduced to a person) (Blagovechtchenski, Gnedykh, Kurmakaeva, Mkrtychian, Kostromina \& Shtyrov, 2019). However, perhaps it should be added - every conscious child.

The dialectical relationship between the concepts of a Subject, a Person, an Individual is concretized and revealed. We think that the subject is a kind of nucleus, which contains the activity and consciousness of human existence as an individual and as a person. The author points out to the subjective existence of the person and individuality. An entity acts as an individual one if it knows and acts within the normative field of the society, masters these norms and implements them in people's activities. If the subject creates norms and a fundamentally new activity is based on their basis, then he / she acts as an individual. Thus, the relevance-introduction is determined by the criterion of dilution of these concepts. Unfortunately, the author does not raise the issue of the pre-personal existence of the subject, which, apparently, was not the subject of the research. Therefore, the relationships between these concepts in the genesis are unclear.

Another way of organizing a discussion of a problem situation was to use several options to solve problems from which pupils chose the best. For example, when organizing a discussion of the problem "What is the best hobby?" the teacher conducted a questionnaire and found out the preferences of the pupils. In teacher's address to the pupils he / she noted that each of their preferences in their own way is interesting and useful. Then the pupils had a task with identifying the most exciting and useful lesson. The choice of one of several solution options stimulated foreign language activities of the pupils. In the same way, the discussion of the following problem situations was organized: What is the best way to spend your leisure time? What is the most interesting way to travel? What do you want to be?

C Ternovyk Nataliia, Hudyma Oleksandr

DOI (article): https://doi.org/10.32626/2227-6246.2021-51.190-214 


\section{Teacher:}

- The week-ends are coming. Each of you has your own plans to spend a free-time. Very often we can hear different discussions about the best ways to spend the leisure time. What is your opinion according to this? Is it important to choose the way of spending your leisure time carefully or let it go by itself?

\section{Group I.}

\section{Pupil 1:}

- I think that we don't have to sit and choose what way is better and what is not. It's not for us to decide. Everything must be natural. When you want to do something the only thing you need is desire. Only in this case you will have the real holiday, not expectable and surprising.

\section{Pupil 2:}

- I totally disagree. In order to have a good leisure time you must plan it forehead. Of course you can't plan every detail but in general you must know what to do. To my mind planning a walking trip is better than just sit, read a book and wait for a somebody's call.

\section{Pupil 3:}

- Easier said than done. It never happens as you wish. Sometimes it seems to you that everything is planed and nothing can go wrong. But you cannot tell forehead what can happen and your dream can be broken to pieces.

In control groups the discussion of these topics was carried out according to the traditional question-answer methodology.

\section{Teacher:}

- What can you tell me about your leisure time? Where do you prefer to spend it?

\section{Group II.}

Pupil 1:

- I am always looking forward for my free-time. In this period I can finally relax and do whatever I want.

\section{Pupil 2:}

(C) Ternovyk Nataliia, Hudyma Oleksandr DOI (article): https://doi.org/10.32626/2227-6246.2021-51.190-214 
DOI: https://doi.org/10.32626/2227-6246.2021-51 2021. випУСК 51

- The leisure time is the most precious time for me. I prefer playing chess because I am a big fan of this game.

\section{Pupil 3:}

- I don't have any leisure time so I can't say what I prefer. During so called «leisure time» I have practical lessons with my tutor.

The important place in the teaching of a foreign language was moral and ethical problem situations. They had not only educational but also cultural effect on schoolchildren. To organize a discussion of the moral and ethical problem the teacher reported to the pupils incomplete output data. So, to create one of the problem situations on "What is wrong? a great introduction of the teacher and a series of sequential pictures were prepared. In the introduction, the teacher set a problem for pupils in the form of a problem: "One day some pupils went to the theatre. They were two boys and three girls. The performance was splendid but the girls didn't like their visit to the theatre. Explain why the girls didn't like it. Find the answer in the cards». After that pupils looked through the cards and analyzed the schoolchildren's behaviour at the theatre: "The boys didn't help with their coats and hats. The boys spent too much time eating their cakes and drinking lemonade, and they came back late to their seats». These facts allowed the pupils to fill in the information that was missing during the problem setting and to conclude some moral and ethical norms of conduct.

Incomplete output, without which the search for an answer to the question put by the teacher was impossible, served as an incentive for the thought-making activity of pupils. Similarly it was organized the topic «The world around teens is full of problems».

After the introductory word of the teacher, the pupils were asked to write a letter of how they would like people to behave in their ideal world. Then a discussion of the topic was held: «The relations between friends».

(C) Ternovyk Nataliia, Hudyma Oleksandr

DOI (article): https://doi.org/10.32626/2227-6246.2021-51.190-214 
At the previous stage pupils were invited to discuss the words of famous people regarding friendship.

\section{Teacher:}

- The sea of friendship is now calm and beautiful. But sometimes it can be horrible and dangerous! Do you want to sail in it? Are you sure you are ready for that voyage? There are some expressions of famous people written on the blackboard. Agree or disagree with them and prove your ideas. It will be your ticket to our ship.

"Be slow in choosing a friend, slower in changing".

Benjamin Franklin

"The best way to destroy your enemy is to make him your friend».

Abraham Lincoln

"Money can't buy friends, but you get a better class of enemy».

Spike Milligan, Irish comedian

"Associate with men of good quality, if you esteem your own reputation, for it is better to be alone than in bad company".

George Washington

This task helped the pupils to determine their position on friendship in such a way, and also helped to reduce the fear of expressing their own thoughts before the whole class. Here are some of their answers.

\section{Group III.}

\section{Pupil 1:}

I fully agree with Benjamin Franklin. Choosing a friend is a very important mission and we mustn't make it easy, otherwise we may choose the wrong person and feel sorry for the rest of our lives.

Pupil 2:

- People say: "Tell me who is your friend and I'll tell you who you are.» I couldn't say better. Everybody knows that to find a real friend is very difficult. But when you have found such person you must do everything in order not to loose it.

(C) Ternovyk Nataliia, Hudyma Oleksandr DOI (article): https://doi.org/10.32626/2227-6246.2021-51.190-214 
Group II.

\section{Pupil 1:}

- I prefer the expression of Abraham Lincoln to the expression of Benjamin Franklin. Because we all know the fact that from love to hate is one step and on the contrary. And a loyal enemy can be turned into the loyal friend. Of course it requires great efforts, but such friend is dangerous because under the certain circumstances he may turn back into the enemy.

\section{Pupil 2:}

- Spike Milligan had a very good point. Though money and friendship cannot be put into one line, we all are aware in the importance of it. But on the other hand I must say that it doesn't matter how much money your enemy has, the only thing that can be better is the method he will use to destroy you. That is a disadvantage. You can also see a good point of such enemy. He can teach you lots of useful things and for the future you will know how to protect yourself correctly.

\section{Pupil 3:}

- I can only partly agree with George Washington. Yes, there are some people who prefer loneliness to a bad company, but it is very difficult to be lonely. Mostly it depends on the character of the person.

The task for control groups was simply to express their views on the above-mentioned expressions.

\section{Group I.}

\section{Pupil 1:}

- As for me I like to choose friends fast without thinking. That's why I have a lot of friends.

\section{Pupil 2:}

- I like the expression of Abraham Lincoln though I can't even imagine how to make your enemy your friend.

\section{Group II.}

\section{Pupil 1:}

- I don't agree with the expression of Spike Milligan because, for example, rich people have a great number of friends (C) Ternovyk Nataliia, Hudyma Oleksandr

DOI (article): https://doi.org/10.32626/2227-6246.2021-51.190-214 
and acquaintances. With their help they can do everything and not to be afraid of anything.

\section{Pupil 2:}

- I like the expression of George Washington but I can only partly agree with him. Sometimes bad company has its own advantages. I mean after spending time with such company you already know what to expect from your enemies.

The next stage was the consideration of problem situations. Group I.

\section{Teacher to pupil A:}

- You notice that your friend B doesn't look very well. Find out what the matter is. Give your friend a word of advice.

\section{Teacher to pupil B:}

- You are worried. You can't sleep at night. You're tired of your relationships with your boy-friend. You are really good friends with him. But the problem is he explodes about little things and takes the blame out on you by punching you. Ask pupil A for her advice.

In the process of a heuristic conversation, the pupils were offered a table for help. After that the teacher turns to the whole class with a question:

- Do you agree with your classmate's opinion? Will it be better to leave her boy-friend without any explanations in order to save her nerves, or to have a serious conversation and find the way out of this situation? Prove your opinion.

\section{Pupil 1:}

- To my mind it will be better to have a serious talk about their problems and to discover the reasons of his behavior. Maybe it is just a misunderstanding. But in order to make all these actions she will have to try hard otherwise there will be no result. We all know that to achieve something you need to use the best efforts you have ever had. If she wants to stay with her boy-friend and be happy it is necessary for her to take hazards and decide the destiny by herself. Nobody will help. It's all up to her. 
Pupil A

Pupil B

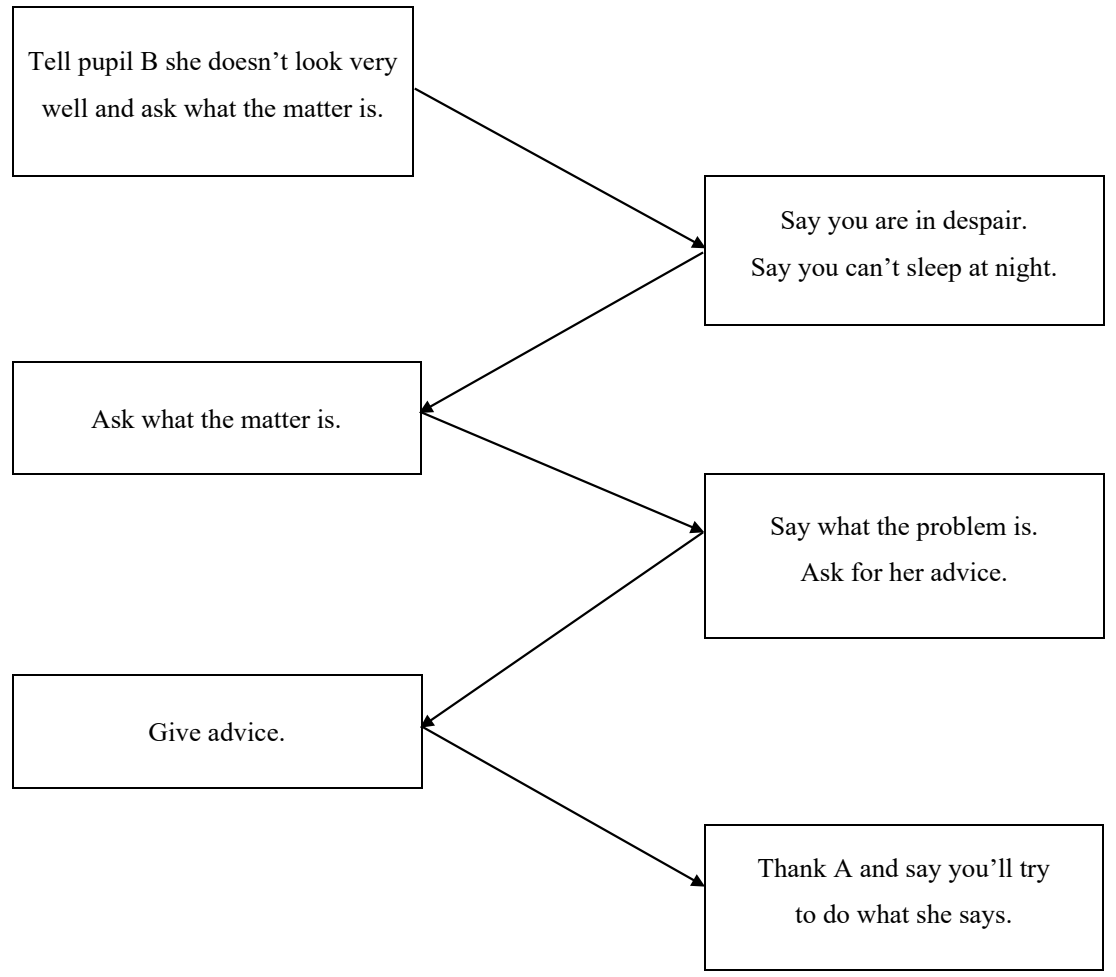

\section{Pupil 2:}

- You are probably right. But don't you think that it will be much easier to forget about everything negative that you've had and to start building the relations from the very beginning. While discovering the reason you can make everything only worse. I guess it's high time for them to move in different directions. They both must realize it and leave taking a good memories with themselves.

\section{Pupil 3:}

- I agree with you only to a certain extent, but still it seems to me that she must have courage and face up all the (C) Ternovyk Nataliia, Hudyma Oleksandr

DOI (article): https://doi.org/10.32626/2227-6246.2021-51.190-214 
problems. Only after that she will be able to get rid of this headache. To mind it doesn't matter what difficulties you may meet in your life. The only thing that matters is the way you will stand before them.

Current experimental data suggest that group activity has a positive effect on individual pupils' activity. In our experiments we found that the productivity of random memorization of words (the reproduction) of pupils in the presence of others increased by $3 \%$, and in terms of joint activities - by $25 \%$. Thus, in the conditions of interaction of pupils the exchange of information communication performs the function of forming a common memory fund.

The results of experiments conducted under the direction to solve problems that require a creative approach are indicative for the confirmation of greater efficiency of group activity in comparison with individual. In this research a large number of pupils were offered the same task. During 30 minutes provided for solving the problems, none of the pupils were able to cope with it, working individually. Then the task was offered to groups of the same pupils, united by $2-3$ and 4 people. $70 \%$ of the groups found the right solution without going beyond the same 30 minutes.

Practical experience in the use of group forms of the activity at the lessons allows us to explore the relationships between the effectiveness of joint activities of pupils in the process of group activity on the effectiveness of individual solution by partners in the process of communication of mental problems. At the lessons groups of pupils (3-4 pupils in each group) were asked to solve some problem. As an indicator to assess the effectiveness of joint activities of adolescents in the process of group activity, we used the measure of a teacher's assistance to pupils. As a result, teenagers were divided into subgroups (depending on how much help they needed from the teacher in solving the problem).

C Ternovyk Nataliia, Hudyma Oleksandr DOI (article): https://doi.org/10.32626/2227-6246.2021-51.190-214 
DOI: https://doi.org/10.32626/2227-6246.2021-51

The first (best) subgroup included groups of pupils who showed the highest level of efficiency in solving problems in the process of joint activity, the second (average) - groups with average efficiency, the third (worst) - triads with the least efficiency in the performance of tasks (see Table 1).

Table 1

The effectiveness of groups of adolescents in the process of solving by them mental problems (in the paradigm of group activity)

\begin{tabular}{|c|c|}
\hline Groups & $\begin{array}{c}\text { The average rank of the measure of the assistance } \\
\text { for each group (the scale from } \mathbf{1} \text { to } 20)\end{array}$ \\
\hline I & $2.4-6.5$ \\
\hline II & $7.9-10.1$ \\
\hline III & $11.3-16.6$ \\
\hline
\end{tabular}

Thus, the effectiveness of the members of the primary groups in the individual solution of problems influenced the success of the joint activity of pupils. These data allow us to conclude that the joint activities of adolescents during group activity are characterized by specific factors that, despite the equal composition of groups of teenagers, lead to different effectiveness of the activity in these groups, which, in turn, depends on the effectiveness of the solution problem task by each participant of communication separately.

\section{Conclusions}

These factors must be taken into account by teachers in the classroom to increase the level of knowledge of pupils in this or that subject and improve the methods of working with pupils within the implementation of an individual approach to each individual adolescent. It should be emphasized that the effectiveness of group forms of work at the lessons is largely determined by the level of the activity of pupils' thinking, which in turn will depend on several conditions:

(C) Ternovyk Nataliia, Hudyma Oleksandr

DOI (article): https://doi.org/10.32626/2227-6246.2021-51.190-214 
- whether pupils will receive knowledge ready, if the teacher fully explains the new topic (but does not retell the task, accompanying the translation with the only correct explanation and evaluation of the material, which sometimes occurs in the pedagogical practice of teachers);

- whether the teacher seeks to include pupils into the process of studying the material through leading questions;

- whether the study of new material is carried out in the process of independent search activity of pupils who, when faced with a problem situation, themselves seek a way out of it, thus solving a cognitive problem.

\section{Literature}

Abrams, D., \& Hogg, M. (1999). Social Identity and Social Cognition. Oxford. $350 \mathrm{p}$.

Adler, A., Lindzey, G., \& Hall, C. (1997). Individual Psychology. Theories of Personality, (pp. 114-156). New York : New York Wiley.

Beauvillain, C. (1994). Morphological structure in visual word recognition: Evidence from prefixed and suffixed words. Language and Cognitive Processes, 9 (3), 317-339.

Bennett, M. (1998). Basic concepts of Intercultural Communication: Selected Readings. Yarmouth. $232 \mathrm{p}$.

Binet, A. (1984). Modern ideas about children. S. Heisler (Transl.). Cambridge : Cambridge University Press. 235 p.

Blagovechtchenski, E., Gnedykh, D., Kurmakaeva, D., Mkrtychian, N., Kostromina, S., \& Shtyrov, Y. (2019). Transcranial direct current stimulation (tDCS) of Wernicke's and Broca's areas in studies of language learning and word acquisition. Journal of Visualized Experiments, (pp. 37-59). URL : https://doi.org/10.3791/59159.

Bondarenko, A. F., \& Levenetz, A. E. (2000). Emotionale Abhängigkeiten in Sachen Liebe: eine experimentelle Studie. Psychologie in Osterreich, 1, pp. 24-29).

Brédart, S. (1991). Word interruption in self-repairing. Journal of Psycholinguistic Research, 20, 123-137. URL : https://doi.org/10.1007/ bf01067879.

Britell, T. K. (1980). Competence and Excellence. Minimum Competency Achievment Testing, (pp. 23-29). R. M. Taeger, C. K. Titlt (Eds.). Berkeley. 
Caljuve, A. de, Marx, E., \& Petra, M. (1993). School Development: Models and Changes. Luxembourg. $252 \mathrm{p}$.

Chen, R. (1993). Responding to Compliments. A Contrastive Study of Politeness Strategies between American English and Chinese Speakers. Journal of Pragmatics, 20 (1), 49-73.

Crookes, G. (1989). Planning and interlanguage variation. Studies in Second Language Acquisition, 11, 367-383. URL : https://doi.org/10.1017/ s0272263100008391.

Das, J. P. (2009). Das-Naglieri cognitive assessment system. Chicago : Riverside Publishing. $135 \mathrm{p}$.

Drobot, O. V. (2013). Managerial Mentality: Scientific Paradigm of Research. Middle-East Journal of Scientific Research, 13 (Special Issue on Socio-Economic Sciences and Humanities), 101-107. URL : http://www.idosi.org/mejsr/mejsr13(sesh)13/19.pdf.

Dubovyk, S. H., Mytnyk, A. Ya., Mykhalchuk, N. O., Ivashkevych, E. E., \& Khupavtseva, N. O. (2020). Preparing Future Teachers for the Development of Students' Emotional Intelligence. Journal of Intellectual Disability - Diagnosis and Treatment, 8 (3), pp. 430-436. URL : https://www.lifescienceglobal.com/journals/journal-ofintellectual-disability-diagnosis-and-treatment/volume-8-number-3/ 82-abstract/jiddt/4038-abstract-preparing-future-teachers-for-thedevelopment-of-students-emotional-intelligence. DOI https://doi. org/10.6000/2292-2598.2020 08.03.20. Published: September 14, 2020.

Mykhalchuk, N., \& Bihunova, S. (2019). The verbalization of the concept of «fear" in English and Ukrainian phraseological units. Cognitive Studies |Études cognitives, 19, 11. Warsaw (Poland). URL : https:// doi.org/10.11649/cs.2043.

Onufriieva, L., Chaikovska, O., Kobets, O., Pavelkiv, R., \& Melnychuk, T. (2020). Social Intelligence as a Factor of Volunteer Activities by Future Medical Workers. Journal of History Culture and Art Research, 9 (1), 84-95. DOI http://dx.doi.org/10.7596/taksad.v9i1.2536. URL : http://apps.webofknowledge.com/full_record.do?product=WOS $\&$ search_mode $=$ GeneralSearch\&qid $=3 \&$ SID $=$ C 2 rooGzb9Eyq 41 CkoTY\&page $=1 \&$ doc $=1$.

Vovk, M., Emishyants, O., Zelenko, O., Drobot, O., \& Onufriieva, L. (2020). Psychological Features of Experiences of Frustration Situations in Youth Age. International Journal of Scientific \& Technology Research, 8 (01, January), 920-924. URL : http://www.ijstr.org/ paper-references.php?ref=IJSTR-0120-28117.

C Ternovyk Nataliia, Hudyma Oleksandr

DOI (article): https://doi.org/10.32626/2227-6246.2021-51.190-214 


\section{References}

Abrams, D., \& Hogg, M. (1999). Social Identity and Social Cognition. Oxford.

Adler, A., Lindzey, G., \& Hall, C. (1997). Individual Psychology. Theories of Personality, (pp. 114-156). New York : New York Wiley.

Beauvillain, C. (1994). Morphological structure in visual word recognition: Evidence from prefixed and suffixed words. Language and Cognitive Processes, 9 (3), 317-339.

Bennett, M. (1998). Basic concepts of Intercultural Communication: Selected Readings. Yarmouth.

Binet, A. (1984). Modern ideas about children. S. Heisler (Transl.). Cambridge : Cambridge University Press.

Blagovechtchenski, E., Gnedykh, D., Kurmakaeva, D., Mkrtychian, N., Kostromina, S., \& Shtyrov, Y. (2019). Transcranial direct current stimulation (tDCS) of Wernicke's and Broca's areas in studies of language learning and word acquisition. Journal of Visualized Experiments, (pp. 37-59). Retrieved from https://doi.org/10.3791/59159.

Bondarenko, A. F., \& Levenetz, A. E. (2000). Emotionale Abhängigkeiten in Sachen Liebe: eine experimentelle Studie. Psychologie in Osterreich, 1, 24-29.

Brédart, S. (1991). Word interruption in self-repairing. Journal of Psycholinguistic Research, 20, 123-137. Retrieved from https://doi.org/ $10.1007 / \mathrm{bf01067879.}$

Britell, T. K. (1980). Competence and Excellence. Minimum Competency Achivment Testing, (pp. 23-29). R. M. Taeger, C. K. Titlt (Eds.). Berkeley.

Caljuve, A. de, Marx, E., \& Petry, M. (1993). School Development: Models and Changes. Luxembourg.

Chen, R. (1993). Responding to Compliments. A Contrastive Study of Politeness Strategies between American English and Chinese Speakers. Journal of Pragmatics, 20 (1), 49-73.

Crookes, G. (1989). Planning and interlanguage variation. Studies in Second Language Acquisition, 11, 367-383. Retrieved from https://doi.org/ 10.1017/s0272263100008391.

Das, J. P. (2009). Das-Naglieri cognitive assessment system. Chicago : Reverside Publishing.

Drobot, O. V. (2013). Managerial Mentality: Scientific Paradigm of Research. Middle-East Journal of Scientific Research, 13 (Special Issue on Socio-Economic Sciences and Humanities), 101-107. Retrieved from http://www.idosi.org/mejsr/mejsr13(sesh)13/19.pdf.

(C) Ternovyk Nataliia, Hudyma Oleksandr

DOI (article): https://doi.org/10.32626/2227-6246.2021-51.190-214 
Dubovyk, S. H., Mytnyk, A. Ya., Mykhalchuk, N. O., Ivashkevych, E. E., \& Khupavtseva, N. O. (2020). Preparing Future Teachers for the Development of Students' Emotional Intelligence. Journal of Intellectual Disability - Diagnosis and Treatment, 8 (3), 430-436. Retrieved from https://www.lifescienceglobal.com/journals/journal-ofintellectual-disability-diagnosis-and-treatment/volume-8-number-3/ 82-abstract/jiddt/4038-abstract-preparing-future-teachers-for-thedevelopment-of-students-emotional-intelligence. DOI https://doi. org/10.6000/2292-2598.2020. 08.03.20. Published: September 14, 2020.

Mykhalchuk, N., \& Bihunova, S. (2019). The verbalization of the concept of "fear" in English and Ukrainian phraseological units. Cognitive Studies |Études cognitives, 19, 11. Warsaw (Poland). Retrieved from https://doi.org/10.11649/cs.2043.

Onufriieva, L., Chaikovska, O., Kobets, O., Pavelkiv, R., \& Melnychuk, T. (2020). Social Intelligence as a Factor of Volunteer Activities by Future Medical Workers. Journal of History Culture and Art Research, 9 (1), 84-95. DOI http://dx.doi.org/10.7596/taksad.v9i1.2536. Retrieved from http://apps.webofknowledge.com/full_record. do product $=$ WOS\&search_mode $=$ Generalsearch\&qid $=3 \& S I D=$ C2rooGzb9Eyq4lCkoTY\&page $=1 \&$ doc $=1$.

Vovk, M., Emishyants, O., Zelenko, O., Drobot, O., \& Onufriieva, L. (2020). Psychological Features of Experiences of Frustration Situations in Youth Age. International Journal of Scientific \& Technology Research, 8 (01, January), 920-924. Retrieved from http://www.ijstr. org/paper-references.php?ref=IJSTR-0120-28117.

Терновик Наталія, Гудима Олександр. Евристична бесіда як засіб формування підлітка як суб'єкта пізнавальної діяльності

\section{АНОТАЦІЯ}

Мета дослідження-обгрунтувати методологічні засади з метою дослідження суб'єктності особистості й емпірично перевірити рівень сформованості суб'єктності школярів у підлітковому віці у процесі організації вчителем евристичної бесіди на уроках в освітньому процесі школи.

Для розв'язання поставлених у роботі завдань використано такі теоретичні методи дослідження: категоріальний, структурно-функціональний, аналіз, систематизація, моделювання, узагальнення. В якості експериментального методу використано метод анкетування. 3 (C) Ternovyk Nataliia, Hudyma Oleksandr

DOI (article): https://doi.org/10.32626/2227-6246.2021-51.190-214 http://journals.uran.ua/index.php/2227-6246 
метою проведення емпіричної частини дослідження було розроблено авторські анкети як для батьків, так і для вчителів.

Результати дослідження. Отримані експериментальні дані свідчать про те, що групова робота позитивно впливає на індивідуальну діяльність учнів. У наших експериментах установлено, що продуктивність довільного запам'ятовування слів (відтворення) в умовах присутності інших школярів збільшилася на 3\%, а в умовах спільної діяльності на 25\%. Отже, в умовах взаємодії учнів обмін інформацією, спілкування виконують функцію утворення спільного фонду пам'яті. Показовим для підтвердження більшої ефрективності групової діяльності порівняно з індивідуальною є результати проведених нами експериментів із розв'язання задач, що вимагають творчого підходу. В цьому дослідженні великій кількості учнів пропонували одну й ту ж саму задачу. Впродовж 30 хвилин, які відводилися на розв'язання задач, жоден з учнів не зміг упоратися з нею, працюючи індивідуально. Потім задача була запропонована групам із тих самих школярів, об'єднаних по 2-3 та 4 учні. 70\% груп знайшли правильний розв'язок, не виходячи за рамки тих самих 30 хвилин.

Практичний досвід застосування групових форм роботи на уроках дав нам змогу дослідити залежність між ефрективністю спільної діяльності школярів у прочесі групової роботи від ефективності індивідуального розв'язання мисленнєвих задач партнерами по спілкуванню. На уроках групам школярів (по 3-4 учні в кожній групі) пропонували розв'язати проблемну задачу. Як показник для оцінки ефективності спільної діяльності підлітків у процесі групової роботи ми використовували міру допомоги вчителя учням. У результаті учні були поділені на підгрупи (залежно від того, якої допомоги вони потребували від вчителя у прочесі розв'язання проблемної задачі). До першої (кращої) підгрупи увійшли школярі, які показали найвищий рівень ефективності в розв'язанні завдань у процесі спільної роботи, до другої (середньої) - учні, які мають середні показники ефективності, до третьої (гіршої) - тріади з найменшою ефективністю у виконанні завдань.

Висновки. Окреслені чинники необхідно враховувати вчителям на уроках для підвищення рівня знань школярів із навчальних предметів й удосконалення прийомів роботи з учнями в межах здійснення індивідуального підходу до кожного окремого підлітка. Необхідно підкреслити, щяо ефективність групових форм роботи на уроках значною мірою визначається рівнем активності мислення школярів, що, своєю чергою, залежатиме від

(C) Ternovyk Nataliia, Hudyma Oleksandr DOI (article): https://doi.org/10.32626/2227-6246.2021-51.190-214 
DOI: https://doi.org/10.32626/2227-6246.2021-51 2021. випУСК 51

декількох психологічних умов: чи отримують учні знання готовими, тобто вчитель повністю пояснює нову тему (але не розтлумачує завдання досить детально, супроводжуючи обгрунтування єдиним «правильним» поясненням та оцінюванням матеріалу, щуо нерідко трапляється в педагогічній практиці вчителів); чи прагне вчитель шляхом навідних запитань включити у процес вивчення матеріалу самих учнів; чи вивчення нового матеріалу здійснюється у процесі самостійної пошукової діяльності учнів, які, опинивиись перед проблемною ситуацією, самі иукають із неї вихід, розв'язуючи таким чином пізнавальну задачу.

Ключові слова: евристична бесіда, суб'єкт навчальної діяльності, мислення учнів, прочес спільної діяльності, взаємодія учнів, спілкування, психічні проблеми.

Терновик Наталия, Гудыма Александр. Эвристическая беседа как средство формирования подростка как субъекта познавательной деятельности

\section{АНнОТАЦИЯ}

Цель исследования - обосновать методологические основы с целью исследования субъектности личности и эмпирически проверить уровень сформированности субъектности школьников в подростковом возрасте в процессе организации учителем эвристической беседы на уроках в образовательном процессе школы.

Для решения поставленных в работе задач использованы следующие теоретические методы исследования: категориальный, структурно-функциональный, анализ, систематизация, моделирование, обобщение. В качестве экспериментального метода использован метод анкетирования. С иелью проведения эмпирической части исследования были разработаны авторские анкеты как для родителей, так и для учителей.

Результаты исследования. Полученные экспериментальные данные свидетельствуют о том, что групповая работа положительно влияет на индивидуальную деятельность учащихся. В наших экспериментах установлено, что производительность произвольного запоминания слов (воспроизведение) в условиях присутствия других школьников увеличилась на 3\%, а в условиях совместной деятельности - на 25\%. Следовательно, в условиях взаимодействия учащихся обмен информацией, общение выполняют функцию создания совместного фонда памяти. (C) Ternovyk Nataliia, Hudyma Oleksandr

DOI (article): https://doi.org/10.32626/2227-6246.2021-51.190-214 http://journals.uran.ua/index.php/2227-6246 
Показательными для подтверждения большей эфрфективности групповой деятельности по сравнению с индивидуальной были результаты проведенных нами экспериментов по решению задач, требующих творческого подхода. В этом исследовании большому количеству учеников предлагали одну и ту же задачу. В течение 30 минут, которые отводились на решение задач, ни один из учеников не смог справиться с ней, работая индивидуально. Затем задача была предложена группам из тех же школьников, объединенных по 2-3 и 4 ученика. 70\% групп нашли правильное решение, не выходя за рамки тех же 30 минут.

Практический опыт применения групповых форм работы на уроках позволил нам исследовать зависимость между эффрективностью совместной деятельности школьников в процессе групповой работы и эфрфективностью индивидуального решения мыслительных задач партнерами по общению. На уроках группам школьников (по 3-4 ученика в каждой группе) предлагали решить проблемную задачу. В качестве показателя для оченки эффективности совместной деятельности подростков в процессе групповой работы мы использовали меру помощи учителя ученикам. В результате ученики были разделены на подгруппы (в зависимости от того, какую помощь они требовали от учителя в процессе решения проблемной задачи). В первую (лучшую) подгруппу вошли школьники, которые показали наиболее высокий уровень эффрективности в решении задач в процессе совместной работы, во вторую (среднюю) учащиеся, имеющие средние показатели эффективности, в третью (худшую) - триады с наименьшей эффрективностью в выполнении заданий.

Выводы. Данные факторы необходимо учитывать учителям на уроках для повышения уровня знаний школьников по учебным предметам и совершенствования приемов работы с учащимися в рамках осуществления индивидуального подхода к каждому отдельному подростку. Следует отметить, что эффрективность групповых форм работы на уроках во многом определяется уровнем активности мышления школьников, в свою очередь, будет зависеть от нескольких психологических условий: получают ли учащиеся знания готовыми, то есть учитель полностью объясняет новую тему (но не обосновывает задание целиком, сопровождая его пояснение единственным «правильным» объяснением и оценкой материала, как нередко случается в педагогической практике учителей); стремится ли учитель путем наводящих вопросов вклю-

(C) Ternovyk Nataliia, Hudyma Oleksandr DOI (article): https://doi.org/10.32626/2227-6246.2021-51.190-214 
DOI: https://doi.org/10.32626/2227-6246.2021-51 2021. випУСК 51

чить в процесс изучения материала самих учащихся; осуществляется ли изучение нового материала в процессе самостоятельной поисковой деятельности учащихся, которые, оказавшись перед проблемной ситуацией, сами ищут из нее выход, решая таким образом познавательную задачу.

Ключевые слова: эвристическая беседа, субъект учебной деятельности, мышление учащихся, процесс совместной деятельности, взаимодействие учащихся, общение, психические проблемы.

Original manuscript received January 08, 2021 Revised manuscript accepted February 14, 2021

(C) Ternovyk Nataliia, Hudyma Oleksandr

DOI (article): https://doi.org/10.32626/2227-6246.2021-51.190-214 http://journals.uran.ua/index.php/2227-6246 